\title{
Retraction Note to: Dynamic compaction evaluation using in situ tests in Sagunto's Harbor, Valencia (Spain)
}

\author{
F. Javier Torrijo ${ }^{1} \cdot$ Julio Garzón-Roca ${ }^{1}$ [D $\cdot$ Santiago Alija ${ }^{2} \cdot$ Mário Quinta-Ferreira $^{3}$
}

๑) Springer-Verlag GmbH Germany, part of Springer Nature 2020

\section{Retraction Note to: \\ Environ Earth Sci (2017) 76:658 \\ https://doi.org/10.1007/s12665-017-7033-7}

The authors have retracted their article (Torrijo et al. 2017) because of significant overlap with previously published work (Rodriguez et al. 2015) and the masters thesis of Tomás Vicente Escrig entitled "Proyecto de mejora de rellenos hidráulicos en la explanada de la terminal de graneles sólidos en el Muelle Sur de la ampliación del Puerto de Sagunto", which was defended in 2013 at Universidad Politécnica de Valencia.

F. Javier Torrijo, Julio Garzón-Roca and Santiago Alija agree with this retraction. Mário Quinta-Ferreira has not responded to correspondence about this retraction.

\section{References}

Rodriguez ATP, Montejano JC, Sanz RV (2015) Dynamic compaction evaluation using in situ test. ICE Publishing, London, pp 3039-3044

Torrijo FJ, Garzón-Roca J, Alija S et al (2017) Dynamic compaction evaluation using in situ tests in Sagunto's Harbor, Valencia (Spain). Environ Earth Sci 76:658

Publisher's Note Springer Nature remains neutral with regard to jurisdictional claims in published maps and institutional affiliations.
The original article can be found online at https://doi.org/10.1007/ s12665-017-7033-7.

Julio Garzón-Roca

jugarro@upv.es

1 Department of Geotechnical Engineering, Universitat Politècnica de València, Camino de Vera s/n, 46022 Valencia, Spain

2 Department of Geotechnical Engineering, Universidad Internacional de La Rioja, Av. Gran Vía Rey Juan Carlos I, 41, 28002 Logroño, Spain

3 Department of Earth Sciences, Geosciences Center, University of Coimbra, 3000-272 Coimbra, Portugal 